http://dx.doi.org/10.11646/phytotaxa.177.2.2

\title{
Botanical advances in Southwestern Amazonia: The flora of Acre (Brazil) five years after the first Catalogue
}

\author{
HERISON MEDEIROS ${ }^{1}$, FLÁVIO A. OBERMÜLLER ${ }^{2}$, DOUGLAS C. DALY ${ }^{3 *}$ MARCOS SILVEIRA ${ }^{4}$, \\ WENDESON CASTRO ${ }^{5}$ \& RAFAELA CAMPOSTRINI FORZZA ${ }^{1}$ \\ ${ }^{1}$ Jardim Botânico do Rio de Janeiro, Rua Pacheco Leão 915, 22.460-030, Rio de Janeiro, RJ, Brazil \\ ${ }^{2}$ Programa de Pós-graduação em Ecologia, Instituto de Biologia, Universidade Federal do Rio de Janeiro, Av. Carlos Chagas Filho, \\ 373- Cidade Universitária (Ilha do Fundão), 21941-599, Rio de Janeiro, RJ, Brazil \\ ${ }^{3}$ Institute of Systematic Botany, New York Botanical Garden, 2900 Southern Blvd., Bronx, NY 10458-5126, USA \\ ${ }^{4}$ Centro de Ciências Biológicas e da Natureza, Universidade Federal do Acre, BR-364, km 4, Distrito Industrial, 69.920-200, Rio \\ Branco, Acre, Brazil \\ ${ }^{5}$ Programa de Pós-graduação em Ecologia e Manejo de Recursos Naturais, Universidade Federal do Acre, BR-364, $\mathrm{km} \mathrm{4,} \mathrm{Distrito}$ \\ Industrial, 69.920-200, Rio Branco, Acre, Brazil \\ *correspondence: ddaly@nybg.org
}

\begin{abstract}
Even though it is well known that the flora of Amazonia is severely under-documented, botanical research in the region has been stagnant for the past two decades or more. An exception to this trend has been the international collaboration in the state of Acre, Brazil. The objective of this study was to assess botanical progress in Southwestern Amazonia, specifically the evolution of our knowledge of the flora of the state of Acre five years after production of the first catalogue of its flora. Between 2006-2011, the Acre data-base recorded 2,110 determinations, and among these were 347 new records for Acre, representing an increase of $8.6 \%$ in the known flora, which as of 2011 comprised 4351 species. Of the new records, $6.6 \%$ (23) were new records for Brazil and 14.4\% (50) represented genera new to Acre. The new records comprised 322 species of vascular plants and 22 of non-vascular plants. The most significant finding was that one of every six identifications was a new record for Acre; the total flora of Acre is estimated to be at about 8,000 species. Advances in documentation of the Acre flora have been achieved through institutional partnerships, attention to rescuing and "cleaning" data, mobilizing taxonomic specialists, distributing duplicates to herbaria with significant Amazon collections, and undertaking expeditions to regions of the state that were poorly known or unknown. Indeed, the botanical inventory of Amazonia overall and the management and conservation of the Amazon flora can be realized only through programs that are systematic, integrative and participatory. Every effort must be made to guarantee that the inventory of Amazonia proceeds at least as rapidly as deforestation and development. This necessarily means far greater investment in training, employing, and supporting the field work of productive taxonomists.
\end{abstract}

Key words: biodiversity, botanical inventory, Brazilian Amazon, taxonomy

\section{Introduction}

The Brazilian Amazon represents 49.3\% of that country's territory (Kress et al. 1998), but in the admittedly incomplete checklist of Brazil's vascular flora (Forzza et al. 2010) the Amazon accounted for only $36 \%$ of the total number of species recorded from Brazil. Moreover, the 11,793 Amazonian vascular plant species they recorded (Forzza et al. 2012) comprise $33 \%$ of the 40,000 species estimated to occur in the Amazon region (Mittermeier et al. 2003).

Despite the Amazon's high diversity and despite studies strongly suggesting that plant diversity in the region has been underestimated (Hopkins 2007), floristic inventory efforts have decreased substantially in the past 20 years (Hopkins 2007, Sobral \& Stehmann 2009). One notable exception to this pattern is the state of Acre, located in Southwestern Amazonia on the frontier with Bolivia and Peru. There, floristic inventory was kept at a high rate via collaborative research between the Universidade Federal do Acre (UFAC) and The New York Botanical Garden (NYBG) (Silveira et al. 1997), reaching a milestone with the publication of the first catalogue of the Acre flora in 2008 (Daly \& Silveira 2008) 
Amazonia to be well-collected (Vale \& Jenkins 2012). In contrast, Schulmann et al. (2007) has estimated that 43\% of the Brazilian Amazon has never been collected, $28 \%$ has been poorly documented, and only $2 \%$ can be considered well-collected. Emphasizing geographic gaps in sampling may not be a viable strategy for Amazonia as a whole because of the immensity and large number of sampling gaps, and it may be that strategies for future botanical inventory on a larger scale in Amazonia should focus on under-sampled vegetation types and regions indicated as most likely to harbor novel taxa (e.g., Hopkins 2007).

\section{Conclusions}

Acre is thus far the only region in Amazonian Brazil where an initiative to document a state flora is being implemented effectively. The key to its success thus far has been rescuing and "cleaning" and integrating data, forging institutional partnerships, addressing "black holes," and mobilizing taxonomic specialists. Indeed, the botanical inventory of Amazonia overall and the management and conservation of the Amazon flora can be realized only through programs that are systematic, integrative and participatory. Every effort must be made to guarantee that the inventory of Amazonia proceeds at least as rapidly as deforestation and development. This necessarily means far greater investment in training, employing, and supporting the field work of productive taxonomists. The discovery of new records for the Acre flora, one for every six determinations, continues apace, meaning that botanists need to maintain the pace of their work, not just in Acre but in the Southwestern Amazon Ecoregion as a whole, rescuing data for the relevant parts of Peru and Bolivia and mounting tri-national expeditions, in order to advance botanical knowledge of this region of high importance for conservation.

\section{Acknowledgments}

The Coordenação de Aperfeiçoamento de Pessoal de Nível Superior (CAPES) awarded master's fellowships to Herison Medeiros and Wendeson Castro. The Conselho Nacional de Desenvolvimento Científico e Tecnológico (CNPq) awarded research productivity fellowship to Rafaela Forzza and Ph.D thesis fellowship to Flávio A. Obermuller. We thank parataxonomists Edilson C. Oliveira, Irio Rivera and "Evandrinho" for their invaluable assistance in the field, and the taxonomic specialists whose identifications have made it possible to document so much of the Acre flora. We also thank the students in the University of Acre's Laboratório de Botânica e Ecologia Vegetal for processing and organizing the collections. NY herbarium manager Edgardo Rivera greatly facilitated the processing and identification of the collections arriving in New York. The Beneficia Foundation funded the Mobilizing Taxonomic Specialists project, and the JRS Biodiversity Foundation funded the Rescue and Integration of Botanical Data for Conservation in the Southwestern Amazon project.

\section{References}

Brown, I.F., Brilhante, S., Mendoza, E. \& Oliveira, I. (2002) The highway from Rio Branco, Acre, Brazil to Pacific ports: How to maximize the benefits and minimize the adverse impacts for sustainable development of southwestern Amazonia. In CEPEI, Encuentro Internacional de Integración Regional - Bolívia, Brasil y Peru. Editora CEPEI (Centro Peruano de Estudios Internacionales), Lima, pp. 281-296.

CDB. (2010) COP 10 Decision X/17: Consolidated update of the Global Strategy for Plant Conservation 2011-2020. CBD. Available from: www.cbd.int/decision/cop/?id=12283 accessed 20 Jan. 2014.

Daly, D.C., Costa, D.P. \& Mello, A.W.F. (2005) The 'salão' vegetation of Southwestern Amazonia. Biodiversity and Conservation 15: 2905-2923. http://dx.doi.org/10.1007/s10531-005-3429-x

Daly, D.C. \& Silveira, M. (2008) Primeiro Catálago da Flora do Acre, Brasil/First Catalogue of the Flora of Acre, Brazil. EDIUFAC, Rio Branco. 463pp.

Dinerstein, E., Olson, D.M., Graham, D. J., Webster, A. L., Primm, S. A., Bookbinder, M. P. \& Ledec, G. (1995) A conservation assessment of the terrestrial ecoregions of Latin America and the Caribbean. WWF/The World Bank, Washington, D. C., 129 pp.

Forzza, R.C, Baumgratz, J.F.A., Costa, A., Hopkins, M., Leitman, P.M., Lohmann, L.G., Martinelli, G., Morin, M.P., Coelho, M.A.N., Peixoto, A.L., Pirani, J.R., Queiroz, L.P., Stehmann, J.R., Walter, B.M.T. \& Zappi, D.C. (2010) As angiospermas do Brasil. In: Forzza, R.C. (org.) Catálogo de plantas e fungos do Brasil. Vol. 1. Instituto de Pesquisas Jardim Botânico, Rio de Janeiro, 871pp.

Forzza, R.C., Baumgratz, J.F.A., Bicudo, C.E.M., Canhos, D.A.L., Carvalho Jr., A.A., Coelho, M.A.N., Costa, A.F., Costa, D.P., Hopkins, 
M.G., Leitman, P.M., Lohmann, L.G., Lughadha, E.N., Maia, L.C., Martinelli, G., Menezes, M., Morim, M.P., Peixoto, A.L., Pirani, J.R., Prado, J., Queiroz, L.P., Souza, S., Souza, V.C., Stehmann, J.R., Sylvestre, L.S., Walter, B.M.T. \& Zappi, D.C. (2012) New Brazilian floristic list highlights conservation challenges. BioScience 62: 39-45.

http://dx.doi.org/10.1525/bio.2012.62.1.8

Goldenberg, R. \& Meirelles, J. (2011) A new species of Graffenrieda (Merianieae, Melastomataceae) with a calyptrate calyx. Systematic Botany 36: 119-123.

http://dx.doi.org/10.1600/036364411x553199

Hopkins, M.J. (2005) Flora da Reserva Ducke, Amazonas, Brasil. Rodriguésia 56: 9-25.

Hopkins, M.J. (2007) Modeling the known and unknown plant biodiversity of the Amazon Basin. Journal of Biogeography 34: 14001411. http://dx.doi.org/10.1111/j.1365-2699.2007.01737.x

Kress, W.J., Heyer, W.R., Acevedo, P., Coddington, J., Cole, D., Erwin, T.L., Meggers, B.J., Pogue, M., Thorington, R.W., Vari, R.P., Weitzman, M.J. \& Weitzman, S.H.(1998) Amazonian biodiversity: Assessing conservation priorities with taxonomic data. Biodiversity and Conservation 7: 1577-1587.

http://dx.doi.org/10.1023/a:1008889803319

Leonel, M., Pinto, L.S., Aquino, J., Carvalho, S.J. (2008) A estrada do Pacífico: Necessidade e Custos Sócio-Ambientais. Cadernos PROLAM/USP 1: 223-260.

Ministério do Meio Ambiente-Brasil (2001) Avaliação e identificação de ações prioritárias para a conservação, utilização sustentável e repartição de beneficios da biodiversidade da Amazônia brasileira. MMA/SBF, Brasília, 144 pp.

Mittermeier, R.A., Mittermeier, C.G., Brooks, T.M., Pilgrim, J.D., Konstant, W.R., Fonseca, G.A.B. \& Kormos, C. (2003) Wilderness and Biodiversity Conservation. Proceedings of the National Academy of Sciences 100: 10309-10313. http://dx.doi.org/10.1073/pnas.1732458100

Mori, S.A., Cremers, G., Gracie, C., Granville, J.J., Hoff, M. \& Mitchell, J.D. (1997) Guide to the Vascular Plants of Central French Guiana. Part 2. Dicotyledons. Memoirs of the New York Botanical Garden 76: 1-776.

Olson, D., Dinerstein, E., Castro, G. \& Maravi, E. (1996) Identifying gaps in botanical information for biodiversity conservation in Latin America and the Caribbean. World Wildlife Fund, Washington, D.C., 50 pp.

Olson, D.M., Dinerstein, E., Wikramanaya, E.D., Burgess, N.D., Powell, G.V.N., Underwood, E.C., D’amico, J.A., Toua, I.I. , Strand, H.E., Morrison, J.C., Loucks, C.J., Allnutt, T.F., Ricketts, T.H., Kura, Y., Lamoreux, J.F., Wettengel, W.W., Hedao, P. \& Kassem, K. R. (2001) Terrestrial ecoregions of the world: A new map of life on earth. Bioscience 51: 933-938. http://dx.doi.org/10.1641/0006-3568(2001)051[0933:teotwa]2.0.co;2

Ribeiro, J.E.L.S., Hopkins, M.J.G., Vicentini, A., Sothers, C.A., Costa, M.A.S., Brito, J.M., Souza, M.A.D., Martins, L.H., Lohmann, L.G., Assunção, P.A., Pereira, E.C., Silva, C.F., Mesquita, M.R. \& Procópio, L.C. (1999) Flora da Reserva Ducke. Guia de identificação das plantas vasculares de uma floresta de terra firme na Amazônia Central. INPA-DFID, Manaus, 800 pp. http://dx.doi.org/10.2307/4110841

Riina, R. \& Berry, P.E. (2011) Croton maasii (Euphorbiaceae), a new species from the western Amazon region. Blumea 56: 146-148. http://dx.doi.org/10.3767/000651911x589203

Sobral, M. \& Stehmann, J.R. (2009) An analysis of new angiosperm species discoveries in Brazil. Taxon 58: $227-232$.

Schulmann, L., Toivonen, T. \& Ruokolainen, K. (2007) Analysing botanical collecting effort in Amazonia and correcting for it in species range estimation. Journal of Biogeography 34: 1388-1399. http://dx.doi.org/10.1111/j.1365-2699.2007.01716.x

Shepherd, G.J. (2003) Conhecimento de diversidade de plantas terrestres do Brasil. Ministério do Meio Ambiente (MMA), Brasília. Available at www.mma.gov.br/estruturas/chm/_arquivos/ plantas1 (november of 2004).

Silveira, M., Paula, N.M.C., Brown, F.I., Nogueira-Borges, H., Daly, D.C. \& Ferreira, L.A. (1997) Os "buracos negros" da diversidade: estudos no Acre revelam precariedade no conhecimento sobre a flora amazônica. Ciência Hoje 22(128): 64-65.

Taylor, C.M., Janovec, J.P. \& Gereau, R.E. (2011) A new species of Pentagonia (Rubiaceae: Hippotideae) from Southern Peru. Journal of the Botanical Research Institute of Texas 5: 505-511.

Thiers, B. (2014) Index Herbariorum. Part I. The Herbaria of the World. Available at http://sweetgum.nybg.org/ih/ .

Vale, M.M. \& Jenkins, C.N. (2012) Across-taxa incongruence in patterns of collecting bias. Journal of Biogeography 39: 1744-1748. http://dx.doi.org/10.1111/j.1365-2699.2012.02750.x

ZEE-Acre. (2010). Zoneamento Ecológico-Econômico do Estado do Acre, Fase II (Escala 1:250.000): Documento Síntese. 2. Ed. Rio Branco: SEMA, 356 pp. 